\title{
A KÖNYVTÁROS SZEREPE ÉS LEHETÖSÉGEI A KISTELEPÜLÉSEK KÖNYVTÁRI ELLÁTÁSÁBAN ÉS A KÖNYVTÁRBUSZOKON
}

\section{CSOBÁN LÁSZLÓ}

\section{Tartalmi összefoglaló}

A tanulmány érintölegesen a Baranya megyei ún. telepített könyvtári ellátást, hangsúlyosabban pedig a könyvtárbuszos ellátást mutatja be, elsősorban a könyvtáros személyére fókuszálva. Azt a kérdést vizsgálja meg, hogy a könyvtáros szakembernek milyen kompetenciákkal kell rendelkeznie, amikor munkája során a kistelepülések vezetőivel és a helyi lakosokkal együttmüködve alakítja, szervezi a helyi kulturális életet. https://doi.org/10.46280/KOMPKONF.2020.Csoban

\section{Bevezető}

Baranya megye településszerkezete szerint aprófalvas megyeként jellemezhető. A pécsi székhelyű Csorba Győző Könyvtár 283 település könyvtári ellátásáért felel, ebből 225 településen ún. telepített könyvtár működik, míg 58 településre pedig két könyvtárbusz látogat el rendszeresen. A telepített könyvtárak ellátásáért 9 hálózati szakreferens felel, akik egy év során minimum négyszer szállítanak dokumentumokat ezekre a szolgáltatóhelyekre.

Az intézmény első bibliobusza 2010 decemberének elején, egy uniós pályázatnak köszönhetően indult útjára, a második busz 2014 első felében kezdte meg munkáját, szintén uniós forrásnak köszönhetően. A jármüvek felszereltségükben hasonlóak, az első könyvtárbuszon 4000 dokumentum, 2+1 laptop, 30 féle folyóirat, a második buszon 2000 dokumentum, 4+1 PC és ugyancsak 30 féle folyóirat található. Mindkét busz felszerelt nyomtatóval, projektorral, valamint műholdas parabolaantennával (ennek segítségével biztosított az internetelérés a jármü látogatói számára).

A buszok rendszeresen 29 települést látogatnak. Ugyanabba a községbe havonta kétszer jutnak el, egyszer hétköznap, egyszer pedig hétvégén. A településeken másfél órát állnak a buszok, a szolgálatot egy könyvtáros és egy sofőr látja el. A szolgáltatás igénybevétele mindenki számára ingyenes. 


\section{A kőnyvtárbuszos szolgáltatás}

A szolgáltatás müködésének tárgyi és személyi feltételei a következők:

Megállóhely: célszerű, ha a település jól frekventált helyén található, könnyen megközelíthető és a talaj minősége is megbízható, az esetleges süllyedést elkerülendő.

Áramforrás: külföldi példák igazolják, hogy működtethető saját akkumulátorral is a szolgáltatás, azonban az állandó hálózati áramforrás biztosításával megbízhatóbbá válik a másfél órás szolgáltatási idő.

Kontaktszemély: szerencsés, ha a település lakossága által ismert és elfogadott személy látja el a kapcsolattartást; a kijelölt személy segít a szolgáltatás megszervezésében és népszerüsítésében, valamint a lakosság értesítésében.

\section{Kompetenciák}

A CERTIDoc minősítési rendszer részeként ismert LIS Euroguide ${ }^{1}$ útmutató a könyvtáros szakma gyakorlásához húsz alapvető tulajdonságot rendel, mindezt hat szituációba helyezve.

a. Személyes kapcsolatok: önállóság, kommunikációs képesség, nyitottság, empátia

b. Csapatszellem: tárgyalási képesség, pedagógiai érzék

c. Kutatás: rendszerező képesség

d. Elemzés (analízis): elemző képesség, kritikus gondolkodás, szintézisre való képesség

e. Kommunikáció: diszkréció, érzékenység

f. Irányítás: kitartás, precizitás

g. Szervezés: rugalmasság, előrelátás, döntésképesség, kezdeményezőkészség, szervezőkészség

A továbbiakban ezen szituációk és tulajdonságok szerint elemzem a Baranya megyei könyvtárbuszos szolgáltatást.

\subsection{Tárgyalási és kommunikációs képesség}

A megyei könyvtár a könyvtári szolgáltatásról szóló szerződést a települések önkormányzatával köti meg. Magas fokú tárgyalási és kommunikációs képesség nélkül nem lehetséges az érdekérvényesítés. A polgármestert érdekeltté kell tenni abban, hogy támogassa a könyvtári szolgáltatást, például úgy, hogy kialakítja (lekövezteti) a könyvtárbusz megállóhelyét vagy úgy, hogy kiválasztja a legalkalmasabb személyt a könyvtárbusz müködtetői és a lakosság közötti kapcsolattartásra.

1 BARTOS Éva: Bővülő könyvtáros kompetenciák. = Tudományos és Müszaki Tájékoztatás, 61. 3. 2014. 99. p. 
A helyi közösségen belül jó kapcsolatokkal rendelkező, katalizátorként működő kontaktszemély ösztönzően hat(hat) a bibliobuszos szolgáltatás egészére. Furcsa lehet a feltételes mód, de a gyakorlat néha azt igazolta, némely településen „rendelkezésre áll” ugyan egy alkalmas személy a kapcsolattartásra, de más jellemzők miatt ez a hatás nem türöződik a látogatottsági adatokon.

A telepített könyvtárak esetében is nagyon fontos a jó tárgyalási és kommunikációs képesség. A 2015-ben megjelent KSZR (Könyvtárellátási Szolgáltató Rendszer) ajánlása 80-100 négyzetmétert ír elő a szolgáltatóhelyek kívánatos alapterületének, de ennek az elvárásnak a 225 telepített könyvtárból jelenleg 20 felel meg. A helyben foglalkoztatott munkatársak fluktuációja is nehezíti a rendszer működtetését, különösen akkor, ha a távozó munkatárs aktív közremüködője volt a szolgáltatásnak, de az utódjaként felvett kolléga kevésbé motivált a könyvtári feladatok ellátásában. A vonatkozó EMMI rendelet² szerint 2018 után az 1500 fö alatti lakosságszámú települések szolgáltatóhelyein minimum érettségivel rendelkező munkatárs foglalkoztatása szükséges. A települések megtartóereje munkahely vonatkozásában elég alacsony, számos helyen alig akad érettségivel rendelkező személy, akit be lehetne vonni könyvtári foglalkoztatásra.

A könyvtárbuszos tapasztalatokból kitünik, hogy a kontaktszemélyi feladatok ellátásának sikere nem függ a végzettségtől, és ha a rátermettség emberi vonatkozásait nézzük, akkor közelebb jutunk a sikeres szolgáltatáshoz.

\subsection{Csapatmunka, csapatszellem}

A Csorba Győző Könyvtárban 8 fő felelős a könyvtárbuszos szolgáltatásokért. A buszokon egyszerre a gépkocsivezető és egy könyvtáros tartózkodik. Míg az egyik könyvtáros a terepen szolgáltat, addig a másik a háttérmunkát végzi Pécsen. A könyvtárosok egymás közti információcseréje elengedhetetlen, hiszen, ha valamiről nem szerez tudomást a másik, az kihat a szolgáltatásra, legyen szó egy teljesületlen olvasói kérésről vagy a szolgáltatás elmaradásáról.

A településen töltött másfél órát a legtöbb esetben áthatja a csapatszellem. Általános jelenség a forgalmasabb településeken, hogy amíg a könyvtáros visszaveszi a könyveket és elbeszélget vagy éppen információt, könyvet keres a számítógépen a használóknak, addig a gépkocsivezető besorolja a visszahozott könyveket. Előfordul az is, hogy a kölcsönzést is lebonyolítja, amíg a könyvtáros kézműves foglalkozást tart vagy felolvas a gyerekeknek.

A könyvtárbuszon dolgozók összetartása mellett a csapatmunka egy másik aspektusa is tetten érhető a megyei könyvtárban. Hisz tulajdonképpen a Csorba Győző Könyvtár csaknem valamennyi dolgozója részt vesz a könyvtárbuszt érintő munkafolyamatokban. A zökkenőmentes szolgáltatás biztosításához elengedhetetlen a hálózati osztály helyben dolgozó munkatársaival folytatott folyamatos egyeztetés, a feldolgozók, a kötészeten dolgozók, a raktárosok, az olvasószolgálatos kollégák közreműködése és munkája. De ne felejtsük el a könyvtárközi kölcsönzéssel foglalkozó kollégák feladatait és a szaktájékoztatók segítségét

2 39/2013. (V. 31.) EMMI rendelet a Könyvtárellátási Szolgáltató Rendszer működéséről 
sem, vagy a gyermekkönyvtárosok ötleteit egy-egy gyerekfoglalkozás lebonyolításához. A helyismereti osztály dolgozói dokumentálják a könyvtárbuszokkal kapcsolatos híreket, a rendezvényszervezők pedig évente több tucat rendezvényt bonyolítanak le a buszos településeken, a titkárság dolgozói és a vezetőség a szerződések megszövegezésével és a vezetői és adminisztratív feladatok ellátásával segítik a buszok munkáját.

\subsection{Kutatás és elemzés}

A kutatás, illetve elemzés az aktuálisan háttérmunkát végző könyvtáros munkáját érinti. A könyvtárbusz használóinak lehetőségük van dokumentumokat kérni/rendelni a pécsi Tudásközpont állományából is, melyet a következő szolgáltatás alkalmával kapnak kézhez. A használók érdeklődése és információigénye igen szerteágazó, az aquapónia építéstől, Katalin cárnő életén át az ormánsági szőttesekig bezárólag, sokféle kérés érkezik a könyvtároshoz. A könyvtáros dolga felmérni, milyen mélységig érdemes kutatni, információt keresni, vagyis, hogy az olvasó általánosan érdeklődik a téma iránt, esetleg dolgozatot ír majd belőle, vagy a szakdolgozatához szükségesek az információk, illetve dokumentumok, mert ennek megfelelően kapja kézhez a dokumentumot az olvasó.

\subsection{Pedagógiai érzék, naprakészség}

A könyvtárbuszon dolgozó könyvtárosnak az olvasókkal való kapcsolattartásra mindössze havi kétszer másfél óra áll rendelkezésre. Már az első találkozásnál számít, miképpen szólítja meg a könyvtáros a buszba betérőt, pláne ha az óvodás vagy iskoláskorú. Jó pedagógiai érzékkel kiválasztott könyv ajánlásával elérhető, hogy az olvasó bizalommal forduljon a könyvtároshoz a következő alkalommal is. A könyvtárosnak fel kell ismernie, ki az, aki segítségre szorul, és ki az, aki inkább önállóan szeret válogatni a kínálatból. Az olvasók kölcsönzéseit, ízlését figyelve, kifejleszthető legalább kétféle ajánló képesség. Az egyik a keresztajánlás. Például egy törzsolvasó lelkes élménybeszámolója biztos alap lehet az ajánláshoz egy hasonló ízlésű olvasó számára. A másik lehetőség az, amikor a könyvtáros spontán érdeklődik az olvasóktól egy-egy visszaadott könyv tartalmáról, majd a megszerzett információ birtokában magabiztosabban ajánlhatja a dokumentumot más olvasónak is.

Az alapvető elvárás, hogy a könyvtáros ismerje a buszokon lévő állomány összetételét, és rendszeresen cserélje, frissítse is. Az állomány összetétele az olvasói igényekhez igazodva folyamatosan változik. Az első időkben a dokumentumok szerzői betűrendben sorakoztak a polcokon, melyet később felváltott a tematikus elrendezés. Krimi, romantikus regény, kaland/történelem válogató polc könnyíti meg az olvasók dolgát a tájékozódás terén. Az ifuúsági részleg mellett kialakításra került egy ún. „vörös pöttyös” részleg, reflektálva a fiatal felnőtteknek (young adult) szóló kiadványok térhódítására. A sorozatokkal kapcsolatban fontos megjegyezni a naprakészséget, amit a LIS Euroguide ilyen mélységben ugyan nem említ, de az mégis elmondható, hogy az egyik leghatásosabb tekintélyt erősítő eszköz, ha a könyvtáros tisztában van a sorozatok pontos sorrendjével. 


\subsection{Kitartás, szervezökészség, problémamegoldás}

A LIS Euroguide szerint a kitartás definíciója arra világít rá, hogy a könyvtárosnak bármilyen szituációban képesnek kell lenni kitartania az adott tevékenység mellett. Ehhez szorosan hozzátartoznak a szervezés színtjén a következő kompetenciák: rugalmasság, elörelátás, döntésképesség, kezdeményezőkészség, szervezőkészség.

Az évek során kialakultak azok a megoldási rutinok, amelyeket a menet közben felmerülő hibák kezelésére, elhárítására dolgoztak ki (például a könyvtári integrált rendszer, az internetkapcsolat vagy a buszok műszaki állapotának hibáinak kezelése) de mindig adódhatnak olyan szituációk, amelyek váratlan helyzet elé állítják a könyvtárbuszok személyzetét (elakadás a sárban, közlekedés szélsőséges időjárási körülmények között, vagy az informatikai rendszert, a müholdas parabolaantennát, illetve annak rendszerét érintő problémák).

A könyvtárosnak hatékonyan kell fellépnie abban az esetben is, ha alkoholos befolyásoltság alatt lévő látogató tér be a járműbe, és közbe kell avatkoznia, akkor is, ha az olvasó nemkívánatos tartalmat böngészik a neten. A kölcsönzésből adódó bonyodalmak - például a tartozások behajtása - könnyebben kezelhetők azokon a helyeken, ahol a kontaktszemély hatékonyan segíti a szolgáltatást.

\subsection{Precizitás, szabályzat}

A bibliobuszokon a precizitás két aspektusból, a könyvtár mint szolgáltató, és az önkormányzat mint fenntartó szempontjából elemezhető. A könyvtár oldaláról, hogy időben érkezik-e a jármű a településre, értesítik-e a lakosságot a könyvtárbusz érkezéséről, szolgáltatásairól? Hogy a busz az igényeknek megfelelő dokumentumokat biztosítja-e a lakosság részére? Megkapja-e a kérését az olvasó, és azt kapja, amit kért?

Az önkormányzat részéről, hogy teljesítik-e a szerződésben foglaltakat, és biztosított-e a megállóhely, van-e megfelelö áramforrás, kontaktszemély a busz számára stb.

Amennyiben valamelyik oldalon a teljesítés sérül, az negatívan hat a könyvtári szolgáltatásra. Beiratkozáskor a könyvtáros ismerteti a legfontosabb tudnivalókat a kölcsönzéssel kapcsolatosan. A szolgáltatás jellegéből adódóan a kölcsönzési határidő némileg szabadabban kezelt, a dokumentumok egy hónapig maradhatnak az olvasónál, szolgáltatás kimaradásakor nem probléma, ha ez csúszik.

\section{Megoldhatatlan(nak tünő) problémák}

A könyvtáros lehet bármennyire elszánt, jól képzett és megannyi kompetenciával felvértezett, akad néhány olyan jellegü probléma, amivel nem tud mit kezdeni. Ilyenek például a településen élők szociális, megélhetési problémái, vagy a könyvtáros számára átláthatatlan helyi konfliktusok, amelyek akár évtizedek óta léteznek megoldatlanul a településen. (Például 
egy 150 fös településen, a lakosság fele azért nem látogatja a könyvtárbuszt, mert annak „megszervezése” a polgármesterhez köthetö, akivel viszont személyes konfliktusban állnak.)

\section{1. Ördögi kör}

A hátrányos helyzetű településeken megfigyelhető az alábbi jelenség: a településen megszületik egy gyermek, aki az óvodát követően iskolába jár, szakmát tanul. Ezen a ponton már előfordulhat, hogy kollégista lesz, tehát átmenetileg beköltözik egy nagy(obb) városba. Ha tehetséges és az anyagiak is rendelkezésre állnak, akkor bejuthat a felsőoktatásba. Amikor befejezi a tanulmányait, nagy valószínűséggel nem tér vissza a szülőfalujába, mivel az esetek többségében ott, helyben nincs munkalehetőség. Ezért beköltözik egy közeli városba vagy külföldön keres munkát. Az állam, a település, a pedagógus, a szülők, a könyvtáros mind hozzájárultak a gyerek boldogulásához, viszont a település még inkább hátrányos helyzetűvé válik, mert a fiatal felnőtt máshol próbál szerencsét, nem addigi lakhelyén.

\subsection{Kiszámíthatóság}

A leghátrányosabb településeken sok esetben a Maslow-féle piramis alján lévő szükségletek (fiziológiai, biztonsági) sem biztosítottak. Egészen addig, amíg ezek nem, vagy csak részben teljesülnek, addig a piramis tetején elhelyezkedő szintek, mint például a kognitív vagy esztétikai szükségletek (ide értve az olvasást is) természetszerűleg háttérbe szorulnak. Amíg egy többgyermekes családban az anyagiak előteremtése, és a mindennapi betevő élelmiszer biztosítása is kérdéses, addig a kikapcsolódást, pihenést szolgáló eszközök, mint például egy könyv, nem jelentenek prioritást.

\section{Megoldásra váró problémák}

Azokon a településeken, ahová jelenleg a könyvtárbuszok járnak, korábban nem volt könyvtár, vagy ha volt is, többnyire régi, elavult állománnyal rendelkeztek. Kevés helyen alakult ki igazi olvasás- vagy könyvkultúra. Ebből adódóan a könyv sem olyan szerepet tölt be az emberek életében, mint amilyent kellene, illetve az olvasás nem számít értékes időtöltésnek. Kiemelt feladat a könyvtárosok számára (is), hogy a kistelepüléseken tapasztalható alacsony szintű digitális és infokommunikációs készségek fejlesztésére megoldást találjanak. A legtöbb iskolás gyerek kezében megtalálható az okostelefon, és bár 13 éves kor az alsó szint a legismertebb közösségi oldal használatának regisztrációjához, alig találunk olyan alsós gyereket, aki ne lenne regisztrált tagja az oldalnak. Tudatos internet-használatról a legritkább esetben beszélhetünk, nagyon sok még a teendő e téren is. 


\section{5. Összegzés}

Összegzésül elmondható, hogy az alábbi kompetenciák fontosak a bibliobusz-szolgáltatást végzők körében:

- jó tárgyaló- és kommunikációs képesség,

- problémamegoldó képesség és rugalmasság,

- csapatjáték,

- pedagógiai érzék,

- precizitás a háttérmunkában,

- kitartás és lelkesedés.

A „Karrierlehetőségek a könyvtár- és információtudományban”3 című amerikai könyv szerzői szerint a könyvtárbuszos könyvtárosnak „rokonszenves embernek kell lennie, akivel jó együtt lenni, és aki kiszolgál minden egyes korosztályt”.

\section{Irodalom}

39/2013. (V. 31.) EMMI rendelet a Könyvtárellátási Szolgáltató Rendszer müködéséről

BARTOS Éva: Bővülő könyvtáros kompetenciák. = Tudományos és Müszaki Tájékoztatás, 61. 3. 2014. 98-103. p. http://tmt.omikk.bme.hu/tmt/article/view/371/10515 [2018. október 31.]

TAYLOR, T. Allan - PARISH, James Robert: Career opportunities in library and information science. New York, Ferguson, 2009.

Csobán László a pécsi Csorba Győző Könyvtár hálózati szakreferense. A Debreceni Egyetemen kezdte meg informatikus könyvtáros tanulmányait, majd Kaposváron szerezte meg BA diplomáját, a mesterszakot Pécsett végezte el. Nyolc éve járja Baranya megye hátrányos helyzetü településeit a Csorba Győző Könyvtár egyes számú könyvtárbuszával. A könyvtárbusz témáról több publikációja is megjelent. 